December 14,1841 .

Richard Owen, Esq., Vice-President, in the Chair.

A letter from the Society's corresponding member, J. B. Harvey, Esq., was read.

A letter from Mr. Fraser, dated from the mouth of the river Nùn, W. Africa, August 14, 1840, was next read. In the first part of his letter, Mr. Fraser, the naturalist to the Niger expedition, alludes to a collection of 'specimens which he had formed during his passage out, and which he had forwarded to England. This collection consists of three mammals, nearly fifty birds, twenty-eight reptiles, upwards of thirty fishes, and about forty boxes, bags, \&c. containing chiefly insects and shells. The writer expresses a wish that this collection may not be regarded as a specimen of what may be here. after expected, since he had purposely abstained, as much as possible, from using his materials for preserving specimens until his arrival at the Niger.

The letter moreover contains some interesting facts relating to the habits and habitats of certain animals. Among the skins of Mammalia, Mr. Fraser observes, he had forwarded a Galago which was shot at Cape Coast, close to the town, in a tamarind tree, where he also found its nest, built, or rather laid, in a fork formed by the branches. The nest was composed of loose leaves. The animal resembled the Loris gracilis, but its limbs were stouter. 'The following monkeys, Mr. Fraser states, appear to be found in the neighbourhood of Sierra Leone : Troglodytes niger, Colobus ursinus, Cercopithecus fuliginosus, common, Cerc. Sabeus, and Cynocephalus Papio. The banks of the beach are everywhere perforated with large round holes, which the natives informed Mr. Fraser were inhabited by an animal which they call the Ground-pig, which is the Aulacodus Swin. derianus of Temminck. At Bassa, the author of the letter saw some skins of Cercopithecus Diana, said to be common in that district; he also saw a skin of an antelope, apparently the Antilope Ogilbyi, Waterh. At Cape Coast the Cercopithecus petaurista is to be found, and likewise the Colobus leucomeros. Skins of the last-mentioned animal as well as of the Cercopithecus Diona were extremely plentiful at Accra.

'The following paper, by $\mathrm{Mr}$. Lovell Reeve, "On Lingula, a genus of Brachiopodous Mollusks," was then read :-

"'Ihe Lingulae belong to a group of Bivalve Mollusks differing materially in their system of organization from any other of the great tribe of Acephala. 'They have received the title of 'the Brachiopoda, on account of their being provided with two long

No. CVII.-Proceedings of the Zool. Soc. 
spirally twisted arms, and are distinguished by other not less important particulars. The soft parts are differently arranged within the shell from those of other Bivalves; the valves are not united by any ligament, and there is a very distinct change in the arrangement and position of the breathing apparatus. Although Pallas has given a short anatomical description of the Terebratula, it was not until the appearance of Cuvier's memoir on the anatomy of Lingula, that the true characters of these remarkable animals became known; it was then determined that the Brachiopoda should be set apart in a separate and distinct class. The anatomy of the Terebratula and Orbicule has since been most elaborately set forth by Prof. Owen in the Transactions of this Society, and agrees in all its essential particulars with that of the Lingule previously described by Cuvier; subject, however, to certain modifications arising from the different situations they inhabit. The Lingula, which are provided with a long pedicle, commonly live near the surface, and are found at low water, partially buried in the sand for the protection of their fragile shells against the violence of the tides; the Terebratula, on the contrary, are found in deep water, attached in clusters to fragments of rocks and corallines by a bunch of short fibrous tendons issuing through an orifice in the shell.

"The essential points in which these animals differ from other Bivalve Mollusks are as follow:-First, in the position of the soft parts within the shell : in the Brachiopoda the dorsal part of the visceral mass is against one valve, and the ventral part against the other; whilst in most of the Tropiopoda the back is placed directly against the hinge, and the sides against each valve. Secondly, in being provided with a pair of retractile brachia or arms : in the place usually occupied by the branchiæ, are two long spirally twisted arms, generally more or less fringed, and so strongly resembling in some species the branchiæ of the Tropiopoda, that they were at one time thought to be the true organs of respiration. These retractile arms are said to be in constant activity for the purpose of producing an inward current of water for the capture of animalculæ, and other alimentary prey. Thirdly, in the arrangement and position of the branchiæ: instead of the organs of respiration being distinctly formed in lateral lamellæ upon the body, as in the Lamellibranchiate Tropiopoda, they consist of a number of beautiful veins and arteries incorporated within the substance of the two lobes of the mantle. 'The calcifying organ of the Brachiopoda therefore has a double function : in addition to its usual property of secreting the calcareous mucus for the formation of the shell, it is made subservient to the circulation of the aërated water. Prof. Owen observes, 'that in this profuse distribution of vessels over a plain membranaceous surface, we perceive the simplest construction of the waterbreathing organ, presenting a beautiful analogy with the elementary forms of the air-breathing organ in the pulmoniferous Gasteropoda.' In consequence of this new arrangement of the respiratory system, the title of the Brachiopoda has been changed by De Blainville for that of the Palliobranchiata, or mantle-breathing Mollusca. The 
muscular system in these animals appears to be most complex; the Lingulce and Orbicule are provided with three pairs of muscles, and the Terebratule have four. The large muscles are destined to open and close the shell in the absence of a hinge ligament; and the small ones assist in sliding one valve over the other for the admission of water.

"Until within the last few years only one species of Lingula was known, and previous to the publication of Cuvier's memoir, before alluded to, the shell of this singular animal gave rise to much speculation amongst naturalists. Linnæus, upon the discovery of an odd valve of Lingula exhibiting no trace of any hinge ligament, described it as a Patella. Both Rumphius and Favanne took it to be the calcareous shield of a Limax or land-slug. Chemnitz, upon finding that the shell of Lingula was really bivalve, placed it with the Pinnee; and even Dillwyn includes it with the Mytili. Bruguière was the first to distinguish it by its present title in the plates of the 'Encyclopédie Méthorique,' in which he has been followed by Cuvier, Lamarck, and all succeeding writers.

"With regard both to the situation that the Brachiopodous Mollusca should occupy in the natural system, as well as the rank to which they are entitled in the classification, authors have been much divided. By Dumeril and De Roissy they were associated in a particular class with the Lepades, on account of a fancied resemblance in their spirally twisted arms to the cirrous tentacula of those animals; they differ however in not being articulated, and their relation altogether with the Lepades is one of very remote analogy. Cuvier distinguished them as a new and separate class, but still arranged them next in order to the Lepades. Lamarck placed them at the end of his 'Conchiferes monomyaires' merely as a family of that order. Prof. Owen and Deshayes both consider that they are entitled to take the rank of an order; the latter author however admits that there is far less affinity between the Brachiopoda and the rest of the acephalous mollusks, than there is between the acknowledged divisions of Bimuscular and Unimuscular. In the arrangement of $\mathrm{my}$ 'Systematic Conchology' I propose to adopt the still higher rank that was assigned to them by Cuvier, namely, that of a class, placing them according to Lamarck, at the end of the Acephala, upon the presumption that their branchial apparatus presents a modification of structure intermediate between that of the proximate classes, the Tropiopoda and the Gasteropoda.

"The Lingula come with great propriety at the commencement of the class, because they have the nearest affinity with the Tropiopoda; their body is larger in proportion to that of the rest of the Brachiopoda, and although the branchiæ are incorporated within the sub. stance of the mantle, they nevertheless present a certain indication of the lamellar structure. Lamarck placed them at the end of his family of 'Les Brachiopodes,' because, in having referred the Cranice to his fossil family of 'Les Rudistes,' he found it necessary to follow up their affinity with the Orbicula; his arrangement of the genera therefore is the reverse of that I have adopted. 
" The Lingula anatina was for a long time the only species known; another one, the Lingula hians, was described by Swainson in his 'Zuological Illustrations,' and we are indebted to Mr. Cuming for five new ones; two, the Lingulce Audebardii and semen, have been already described by Mr. Broderip in the Transactions of this So. ciety, and I have now the pleasure of introducing three which I believe to be entirely new to science.

Lingula ovalis. Ling. testd angustd, elongàto-ovali, glabrd quasi polita, olivaceo-viridi; apice acuminato; valvis utrinque clausis.

Hab. - ?

Long. $1 \frac{3}{10}$; lat. $\frac{6}{10}$ poll.

"This shell, which approaches rather in appearance to that of the Lingula anatina, may nevertheless be distinguished by its complete oval form; though it is somewhat acuminated at the apex, the umbones are much less prominent, and the valves are more compressed, and more closely united all round.

Lingula tumidula. Ling. testá corned, tenuissimd, rubro-olivaced, subquadrata, versus apicem parùm attenuata, umbonibus vix prominulis ; valvis tumidulis, marginibus irregulariter reflexis.

Hab. ad oras Novæ Hollandiæ.

Long. $2 \frac{1}{1} \frac{1}{0}$; lat. $1 \frac{3}{10}$ poll.

Reeve, Conch. Syst. v. i. p. 180. pl. 125. f. 4.

"The shell of the Lingula tumidula differs materially, both in size and composition, from that of any of the previously known species; it is considerably larger and thinner, and rather horny than calcareous, and the colour of it is a burnt olive-red. From the swollen appearance of the valves $I$ am inclined to think that the shell is perfectly pliable and elastic during the life of the animal.

Lingula compressa. Ling. test corned, tenuissima, valde compressa, fusco-olivaced, subquadrato-ovali, versus apicem attenuatd, umbonibus depressis, indistinctis; valvis utrinque clausis.

Hab. ad Palanam, ins. Masbate, Philippinarum.

Long. $1 \frac{8}{10}$; lat. $1 \frac{1}{10}$ poll.

" This curious species was found by Mr. Cuming in sandy mud at low water at Palanas, Island of Masbate, one of the Philippines. Its shell is of the same thin horny composition as that of the Lingula tumidula; in fact I at first took it to be merely a local variety of that species. Upon comparison however I feel assured that it is distinct; it is more attenuated towards the apex, and from the valves being remarkably compressed and closely united all round, I am induced to suppose that the animal must be proportionably smaller. The two specimens from which the above description is drawn do not exhibit the pallial cilia, which Mr. Cuming's usual care would have protected; they may therefore not have been exserted beyond the margin of the valves. He did not succeed in obtaining the pedicle of this species.

"Mr. Cuming exhibits on this occasion specimens of all the known Lingule from his own collection, and I am not aware that four 
species out of the seven exist in any other. They belong to a class of mollusks of which few recent varieties are known, and may therefore be highly esteemed for their conchological interest."

The next paper read was from Mr. G. B. Sowerby, jun., and is entitled "Descriptions of nine species of the genus Pupina."

Molluscum terrestre.

Gen. Pupina, Vignard.

Testa subcylindrica, vitrea, nitidissima, anfractilus quinque ad sex, penultimo inflato, ultimo paululùm coarctato ; aperturâ circulari, margine crasso, reflexo, ad basin columella inciso, vel emarginato.

Operculum corneum, spirale.

The glassy enamel, which gives a brilliant polish to the small, terrestrial shells composing this genus, seems to distinguish them even from those species of Cyclostoma which most nearly resemble them, in having a pupiform shape, and a notch at the base of the columella. The question has been asked, "Why not make this marginal notch the criterion of the genus?" The answer is found in the following facts : first, the notch is found in Cyclostomata, which have no other character in common with Pupina; second, that several Cyclostomata have a canal at the lower part of the whorl, which if continued would form a similar notch; third, that our Pupina lubrica, which could scarcely be separated from the genus, has but a very slight emargination.

The first species described under this generic name was $P, K e$ raudrenii, published by Vignard in the 'Annales des Sciences,' 1829.

Mr. Grateloup subsequently described $P$. Nunezii under the generic name Moulinsia, neither of these naturalists heing acquainted with the operculum.

All the species here described, with the exception of $P$.antiquata and $P$. Keraudrenii, were recently brought to this country by $M r$. Cuming from the Philippines.

* Species spirâ axe retrorso.

Pupina Nunezir. Moulinsia Nunezii, Grateloup, Ann. Soc. Linn. Bordeaux, 1840. P. Nunezii, Sow. jun., Thesaurus Conchyliorum, part 1.f. 8,9,10,11. Published May 1842. Testa globosa, obliqua ; aperturd magná, margine validè expanso, reflexo, complanato, incisurd triangulari penitùs diviso; labio columellari concavo : anfractu ultimo propè aperturam subcomplanato.

Long. " 50 ; lat. 35 poll.

Hab. ad insulas Samar, Luzon, Catanduanus et Siquijor, Philippinarum.

Var. a. Fusca margine flavido. Samar.

Var. b. Flavida, margine aurantiaco. Albay, ins. Luzon.

Var. c. Fulva rufescens. Ins. Catanduanus.

Var. d. Alba, propè aperturam purpureo-cincta, margine flavido. Ins. Leyte.

More globose than any other species, the spire turned backwards, 
the penultimate whorl elevated, the last whorl flattened in front, the incision of the peritreme deep, the columella grooved, varying in colour from bright orange to cream-white and dark brown; the margin always either orange or yellow. Found on leaves of small plants and low bushes in several of the Philippine Islands.

Pupina peluucida, Sow. jun., Thesaurus Conch. part 1. f. 18, 19, 20. Testa obliqua, subglobosa, pellucida, spirce axe valde retrorso, anfractu penultimo elevato, ultimo complanato margine reflexo, incisurd diviso; columelld lata convext.

Long. $\cdot 30$; lat. $\cdot 20$ poll.

Hab. ad insulas Luzon et Zebu, Philippinarum.

Var. a. Fulva. Daleguete, ins. Zebu.

Var. b. Grisea fulvescens, minor. Bongabon, ins. Luzon.

Smaller, more transparent, and with the spire more bent than the last; the outer lip less expanded, the notch completely dividing the peritreme, and the columella convex. Found on small plants in woods.

* Spirâ penè rectâ.

Pupina lubrica, Sow. jun., Thesaurus Conch. part 1 . f. 12 to 16. Testa subobliqua, cylindrica; spirâ brevi obtusâ, aperturâ rotundatâ; margine anticè subexpanso, paululùm incrassato, ad basin columella vix emarginato; columella callosâ.

Long. $\cdot 35$; lat. $\cdot 25$ poll.

$H a b$. ad insulas Panay, Siquijor, et Luzon, Philippinarum.

Var. a. Fulva. Ins. Panay.

Var. b. Fulva, minor. Ins. Siquijor.

Var. c. Alba, translucida. Ins. Siquijor.

Var. $d$. Grisea fulvescens. Ins. Luzon.

Var. e. Alba. Calauang, Laguna, ins. Luzon.

In this species the notch is scarcely perceptible, and there is a rounded callosity behind the columellar lip. The inner lip is thickened on the body whorl. Found in dense woods on small plants.

Pupina vitrea, Sow. jun., Thes. Conch. part 1. f. 6, 7. T. subelongata, recta, anfractibus subrotundatis, margine expanso, reflexo, complanato, incisura diviso.

Long. $\cdot 50$; lat. $\cdot 25$ poll.

$H a b$. Ins. Mindinao et Luzon, Philippinarum.

Var. a. Fulva, margine luteo. Albay, ins. Luzon.

Var. b. Fulva, margine aurantiaco. Cagayan, pr. Misamis, ins. Mindinao.

The spire is straight and elevated, gradually tapering towards the obtuse apex; the peritreme is expanded and flattened, the notch deep.

Pupina similis, Sow. jun., Thes. Conch. part 1. f. 4, 5. Testa fulva, subelongata, recta, anfractibus subrotundatis, margine pallidè fulvo, expanso, reflexo, rotundato, crasso, incisurá usque ad dorsum diviso.

Long. $\cdot 45$; lat. $\cdot 26$ poll. 
$H a b$. Bolino, provinciam Zambales, ins. Luzon.

Resembling $P$. vitrea, but the margin not flattened, and the notch so deep that it is seen at the back of the shell. Found on leaves of bushes and trunks of trees in the island of Luzon.

Pupina nxigua, Sow. jun., Thes. Conch. f. 17. Testa parva, translucida, alba, cylindrica; anfractu penultimo inflato; margine apertura paululum incrassato, incisura diviso.

Long. $\cdot 26$; lat. $\cdot 16$ poll.

$H a b$. St. Nicholas, ins. Zebu, Philippinarum.

This small, transparent white species has the margin very little thickened, and the notch deep. Found on small plants.

$$
\text { ** Spirâ rectâ, aperturâ bicanaliculatâ. }
$$

Pupina numilis, Jaquenot, Sow. jun., 'Thes. Conch. part 1. f. 2. Testa ovalis, solida, pallidè lutea, anfractibus subrotundatis, ultimo propè aperturam paululùm complanato; aperiurt rotundata, margine crasso, expanso, reflexo; labio interno crasso, posticè plicato; columella crassa, latá, tortiosá, reflexa ; incisurâ ad dorsum lata.

Long. $\cdot 60$; lat. $\cdot 40$ poll.

$\mathrm{Hab}$. — ? Mus. Cuming.

This being a dead shell has lost the brilliancy of the enamel. The teeth or folds at the posterior part of the inner and outer lips form a very distinct canal. The columella is tortuous and turned backwards, and the notch is seen at the back like the canal of a Buccinum.

Pupina Keraudrenir, Vignard, Sow. jun., 'Ihes. Conch. part 1. f. 2. Testa parva, cylindrica, griseo-rufescens; spira obtusd recta; aperturâ parva, margine incisurâ diviso; labio externo levitèr incrassato, posticè subplicato; labio interno plicato.

Long. $\cdot 30$; lat. $\cdot 15$ poll.

Hab. Manilla and Singapore? Mus. Stainforth, Sowerby.

A pupiform species with a posterior canal.

Pupina bicanaliculata, Sow. jun., Thes. Conch. part 1. fig. 1 . Testa parva, ovalis, alba, translucida; anfractibus ventricosis; aperturâ magnâ, margine subexpanso, subincrassato, ad basin columelle inciso; labio interno posticè plicato.

Long. $\cdot 26$; lat. $\cdot 16$ poll.

$H a b$. St. Nicholas, ins. Zebu, Philippinarum.

This species differs from $P$. Keraudrenii in shape, being more ventricose, having a tapering spire, and a very strong fold on the inner lip. Found on small plants in the island of Zebu.

The following paper, entitled "Descriptions of four species of the genus Chiton, brought by $\mathrm{H}$. Cuming, Esq. from the Philippine Islands," also by Mr. G. B. Sowerby, jun., was then read :-

Chrton pulcherrimus. Ch. Testa ovali, angulata, ad dorsum elevatâ, pallidè subviridi, fasciis binis rubris distantibus dorsalibus, 
maculis rubris dorsalibus et lateralibus nonnullas intus viridi; areis centralibus longitudinaliter foveolatim sulcatis; areis lateralibus prominentibus, utrinque granulat 3 tricostatis ; areis terminalibus costis moniliformibus numerosis radiatis; margine minutè squamoso, maculis rubris fasciato.

Long. $\cdot 95$; lat. $\cdot 55$ poll.

$H a b$. Gindulman, ins. Bohol, Philippinarum. H. Cuming legit.

The few specimens of this shell which bave been brought in fine condition present an appearance of exquisite finish and great beauty, both in sculpture and colouring. They were found in the crevices of rocks at low water.

Chiton laqueatus. Ch. testá ovatä, depressáa, granulatá, pallidè fulvâ vel viridescente, purpureo et viridi maculatâ ; cost d dorsali purpureá, sublavi; valvá primá costis quinque laqueatâ; valvis medianis unicostatis ad latera quadratis; valvá ultimá valdè depressâ, margine lato, irregulariter rugoso, rubro, viridi, alboque maculato. Vuriat testá angustiore, margine roseâ.

Long. $\cdot 55$; lat. $\cdot 45$ poll.

$H a b$. Calapan, ins. Mindoro, Philippinarum. H. Cuming legit.

Remarkable for the character of the first valve, which is broadly Huted by five radiating ribs. The four or five central valves, in several specimens, are nearly covered by a dark purple colour, the two last patched with green, and the first nearly white, but subject to some variations. Found in coarse sand among small stones at a depth of nine fathoms.

Chiton floccatus. Ch. testâ ovali depressa, antirè angustata, pallidè fulva ; nigro, fusco, viridi, roseoque maculatd: valvis terminalibus radiatim sulcatis, valvis medianis utrinque unicostatis, areis centralibus longitudinaliter sulcatis; areis lateralibus granulatis, marginibus serratis ; valvá terminali obtusè elevata; margine rubro vel fusco, maculis et punctis albis fasciato.

Long. $\cdot 80$; lat. $\cdot 45$ poll.

Hab. Cagayan, Misamis, ins. Mindinao, Philippinarum. H. Cuming legit.

This species is found at Mindinao, under stones at low water, and at Calapan on small stones, at a depth of fifteen fathoms. The margin is sprinkled with white patches resembling flakes of snow, on a reddish brown ground.

Chiton Luzonicus. Ch. test d ovali, angulata, straminea, viridi longitudinaliter strigatd: valvarum areis terminalibus et lateralibus radiatim granulatis ; arcis centralibus acutè longitudinaliter sulcatis, margine sublavi.

Long. $\cdot 35$; lat. $\cdot 20$ poll.

Hab. Sorsogon, pr. Albay, ins. Luzon, Philippinarum. H. Cuming legit.

This small and apparently insignificant shell is very sharply ribbed in the central areas, and presents a very nicely sculptured surface when viewed through a magnifying glass. The specimens were taken on dead shells at a clepth of fifteen fathoms. 
Mr. Waterhouse laid before the Meeting his descriptions of numerous species of Coleopterous insects from the southern parts of South America, which had been placed in his hands for that purpose by H. Cuming, Esq. and C. Darwin, Esq. 'Those from Mr. Cuming formed part of a collection made by Mr. Thomas Bridges, who expressed a wish that the specimens should be laid before the Zoological Society. Unfortunately, the exact localities of the insects are not mentioned in Mr. Bridges's notes, but there is reason to believe they were collected in the neighbourhood of Petorca. The species described belong to the genera Nyctelia and Listroderes, or are nearly allicd to those two groups.

\section{Section HETEROMERA.}

\section{Family NycteliId As.}

\section{Genus Nyctedia.}

Species from the collection of Thomas Bridges, Esq.

Nyctelia lavis. Nyct. atra, nitida; capite anticè punctis sparsis notato; thorace mediocritèr convexo, latiore plusquàm longo, parte antica angustiore, ad latera modicè rotundato, margine anteriore, pilis brevibus flavescentibus fimbriato, angulis et anticis et posticis productis et subacutis, dorso punctis parvulis dispersis: elytris lavibus convexis, brevibus, ovatis, apice producto et subacuto; carind laterali crenulat $;$; segmentis abdominalibus rugis irregularibus longitudinalitèr impressis.

Long. corp. $11 \frac{1}{2}$ lin. ; lat. $6 \frac{3}{4}$; lat. thoracis, $4 \frac{2}{3}$; long. ib. $2 \frac{3}{4}$.

Black and glossy ; general form ovate ; thorax and elytra convex above, and presenting no distinct sculpturing. Head with scattered punctures in front, smooth behind. Thorax with very fine scattered punctures, and these most numerous on the fore part: parallel with, and at a short distance from the lateral margins of the thorax is an indistinct line on each side, formed by the somewhat abrupt termination of the convex discoidal portion at this part; the space between this line and the outer margin is nearly plane, and presents a few indistinct irregular rugæ, having a tendency to a transverse disposition. The thorax is broader than long, the width to the length bearing very nearly the proportion of 8 to 5 ; the middle of the thorax and hindermost part are about equal in width, but from the middle to the front the width gradually decreases; in front it is emarginated, and the anterior margin is furnished with a fringe of short, dense, yellowish hairs; the posterior margin presents an undulating line, encroaching on the body of the thorax on each side about midway between the mesial line and the posterior angle, which is produced. The elytra are very convex, and nearly of an ovate form; they are widest in the middle, and the apical portion is produced; the lateral keel (which forms the outer boundary of each elytron, viewing the insect from above) is not very prominent, and is indistinctly crenulated : this ridge does not extend to the apex of the elytron, but terminates about two and a half lines from that point: between the 
apex and the terminal point of the keel is an oblique ridge : the sutural portion of the elytra is distinctly indented near the scutellum, and less distinctly so at other parts. The mentum is coarsely punctured: the prosternum and mesosternum are coarsely punctured in the middle, and the punctures are confluent: the metasternum has small and somewhat irregular longitudinal rugx in the middle, and similar rugæ are observable on the first, second, and anterior half of the third abdominal segments. The legs are black, but the tip of the femora and base of the tibiæ are pitchy.

Very many specimens of this species were sent to this country by Mr. Bridges, and as I have reason to believe they will be distributed in most of the public and private entomological collections, $I$ shall regard it as a type for comparison in describing some other species of the same genus.

Nyctelia lavis, var. Rufipes. Many specimens of a Nyctelia agreeing with the $N$. lavis, but differing in having the legs and antennæ of a pitchy red colour, were contained in Mr. Bridges's collection. Of these red-legged specimens, as well as of those having the legs concolorous with the body, there are males and females; but the red-legged specimens are generally rather narrower, and often have a slight trace of transverse depressions on the outer side of the elytra; the difference of form and sculpturing, however, is not constantly combined with the red colouring of the legs and antennæ, and as in some other species of Nyctelia and Epipedonota I have found a similar difference in the colouring of the legs, \&c., I cannot regard that character as specific.

Nyctelia transverso-sulcata. Nyct. atra, nitida; capite anticè sparsìm punctato: elytris vix duplo latioribus quàm longis, anticè potiusquàm posticè angustioribus, angulis productis, subacutis : elytris mediocriter convexis, brevibus, ovatis, apice producto, sulcis haud ad medium attingentibus, profundis et levitèr undulatis, transversim insculptis; segmentis abdominalibus ferè lavibus.

Long. corp. 9 lin.; lat. $5 \frac{1}{4}$.

This species is smaller than the $N$. lavis, and the thorax and elytra are less convex. The head has a few scattered punctures in front, and numerous very fine punctures on the hinder part, near the eyes; the remaining portions are smooth. The thorax is impunctate, but little convex above, and has two indistinct foveæ on each side near the posterior angles, and joining the hinder margin. The elytra are ovate and slightly convex; the apical portion is produced, and has the outer inargin slightly reflected : the lateral keel of the elytra is very prominent, and distinctly crenulated : extending inwards from this keel, to about the middle of the elytron, are a series of transverse and slightly irregular grooves, about fourteen in number, on each elytron; the length of these grooves (the interstices of which are convex) varies so, that they all terminate nearly at the same distance from the suture. On the space between these transverse sulci and the suture are two longitudinal striæ, which are somewhat indistinct, and interrupted in parts, excepting on the apical 
portion of the elytron, where the innermost of the two stria is well marked, and the suture of the elytra is at this part somewhat elevated. Numerous oblique furrows are observable on the produced apical portion of the elytra. The portion of the elytra which lies below the keel presents no distinct sculpturing. The abdominal segment presents scarcely any trace of longitudinal rugæ. The legs are black, but have a slightly pitchy hue.

Species of Nyctelia from the collection formed by C. Darwin, Esq., during the voyage of H.M.S. Beagle.

Nyctelia plicata. Nyet. ovata, nigra, nitida; capite anteriore crebrè punctato, posteriore ferè lavi ; thorace transverso, elytris angustiorc; angulis posticis productis, obtusis, suprà ad medium pauld convexo, et crebrè punctato; elytris latis, subovatis, convexis, sulcis profundis transversalibus, a margine externo ferè ad suturam ductis, plagd suturali profunde indentata.

Long. corp. ( $\delta$ ) 13 lin.; lat. $7 \frac{1}{2}$; vel, long. $11 \frac{1}{2}$ lin., lat. $6 \frac{1}{2}$ lin. Long, corp. ( $q$ ) $12 \frac{2}{3}$ lin., lat. $7 \frac{1}{2}$ lin.

$H a b$. Port Desire.

This species is considerably larger than $N$. lavis; the thorax is proportionately broader and shorter, and the produced apical portion of the elytra is dilated and depressed. The head is thickly punctured in front, and there are numerous punctures at the sides above and behind the eyes. The thorax is about twice as broad as long; the broadest part is behind, but till anterior to the middle it scarcely decreases in width ; from the middle to the fore-part the transverse diameter is gradually lessened, so that the lateral margins form a gentle curve; the anterior portion is emarginated, and the posterior margin is rather strongly sinuated; the anterior angles are acute, and the posterior angles are rounded. The upper surface of the thorax is convex in the middle, but towards the sides it is slightly concave; it is thickly punctured, and the punctures are many of them confluent; on the disc the punctures are much less numerous. The elytra are about one-fourth broader than the thorax (rather less in the male sex), and about one-fourth longer than broad; they are very convex, indented at the suture, and furnished with a series of nearly transverse indentations, about eighteen or twenty in number, which commence at the lateral keel and terminate about one-eighth of an inch short of the suture; the space between these transverse folds and the suture is apparently smooth; but with a moderately strong lens some very minute tubercles may be observed scattered on this part, as well as on the interspaces of the transverse indentations, which are about equal in width to the grooves: the apical portion of the elytra is considerably produced, and the produced part is broad and somewhat depressed, and has the upper surface rugose. The mentum is coarsely punctured, and the under side of the head is thickly punctured : the prosternum is coarsely punctured in the middle, and has some irregular rugæ at the sides; at the lateral margin is a series of small transverse rugæ: the mesosternum and metasternum have irregular rugæ in the middle, and the two first and half of 
the third abdominal segments have small irregular longitudinal rugæ ; the remaining two abdominal segments are finely punctured.

Nycretia Solieri. Nyct. ovata, nigra, nitida; capite anticè punctato, posticè lavi; thorace transverso, elytris angustiore; angulis posticis productis, suprà apud medium paulò convexo, et lavi; elytris anticè apud plagam suturalem levitèr impressis, et sulcis transtersis paulo irregularibus a margine laterali ferè ad suturam ductis.

Long. corp. $11 \frac{3}{4}$ lin.; lat. $6 \frac{3}{4}$ lin.

Hab. Patagonia.

This species resembles the $N$. plicata, but differs in having the thorax smooth; the elytra are rather narrower, and the apical produced part is shorter and broader; they are scarcely indented at the suture, excepting in a slight degree towards the scutellum; the transverse folds are less regular, often dividing into two branches, and approach more near to the suture. A transverse section of the elytra of $N$. plicata would present a convex upper surface near the suture, but at the part where the grooves commence the line would be straight (though sloping downwards to the lateral keel), or even slightly concave; whilst in $N$. Solieri a similar section would present an even convex curve. Scattered punctures are observable on the fore-part of the head, and a shallow transverse depression is situated between the eyes; the thorax is nearly twice as broad as long, convex in the middle, but slightly concave towards the lateral margins: with a moderately strong lens some minute punctures are visible, rather thinly scattered over the surface. The elytra are ovate, the length to the width bearing about the proportion of 7 to 9 .

Nyctelia Darwinit. Nyct. brevitèr ovata, convexa, nigra, nitida ; capite subpunctato; thorace pauld ad partem anteriorem quàm posticam angustiore, lavi, convexo; elytris subrotundatis, valdè convexis, lavibus, marginibus lateralibus crenulatis.

Long. corp. $11 \frac{2}{3}$ lin.; lat. 8 lin.; vel, long. 11 lin.; lat. $7 \frac{1}{4}$ lin. Hab. Port Desire.

This species is remarkable for its broad and very convex form and deficiency of sculpturing, having the upper surface of the thorax and elytra smooth and glossy. The head is finely punctured : the thorax is twice as broad as long, and convex; a groove runs parallel with and close to the lateral margins, and a similar groove is observable on the anterior margin, though here it is less strongly marked. Elytra rather more than one-third broader than the thorax, and the length and breadth are very nearly equal, if we exclude the produced apical portion, which is broad, depressed, and nearly of a semicircular form. The lateral keel is distinctly crenulated, and separated by an adpressed line. The underside of the thoracic segments are rugose in the middle, and the first and second abdominal segments have irregular longitudinal rugæ; the third segment presents a faint trace of similar rugæ at the base; the other segments are smooth. 
The spines at the apex of the posterior tibia are longer than usual in the genus.

Nyctelia Darwinii, var.? minor (long. corp. $8 \frac{2}{3}$; lat. $6 \frac{1}{3}$ ); elytris rotundatis apice pauld producto et angustiore.

$H a b$. Port Desire.

Nrctelia FitzRoyi, Curtis, MSS. Nyct. subrotunda, convexa, nigra, nitida; capite utrinque punctis paucis adsperso; thorace lavi, convexo, anticè latiore, angulis posticis acutis ; elytris rotundatis, ad apicem productis, convexis, lavibus, margine externo crenulato; antennis pedibusque piceo-rubris.

Long. corp. $10 \frac{1}{2}$ lin.; lat. 8 lin.

Hab. Port Desire.

This species was first discovered by Capt. King, and will be hereafter described in detail by $\mathrm{Mr}$. Curtis, whose MS. name I have adopted. Two specimens were found by Mr. Darwin at Port Desire : it approaches very near in size and general characters to N. Daruinii, but differs in having red legs and antennæ, in being of a broader form, in having the legs less rough, the lateral keel of the elytra less prominent, and not so distinctly crenulated, and the spurs or spines at the apex of the posterior tibiæe are much smaller. 'The length of the elytra is rather less than the width, if the produced apical portion be omitted; and if included in the measurement, the length very slightly exceeds the width; they are very convex and smooth, and so is the thorax, which is twice as broad as long, and considerably narrower before than behind. The head is sparingly punctured.

Nyctelia granulata, Curtis, MSS. Nyct. atra, nitida, subrotundata; capite transversim impresso, anticè punctato; thorace subquadrato, ad latera crenulato, supra convexo, lavi; elytris rotundatis, apice paulo productis, suprà convexis, ad suturam depressis, rugis validis et irregularibus obsitis, his in dorso plerumque longitudinalibus et prope latera abliquè dispositis.

Long. corp. $8 \frac{1}{4}$ lin. ; lat. 6 lin.

Hab. Cape Negro.

'This, together with several nearly allied and very remarkable species of Nyctelia, occurs in Capt. King's collection, and will be hereafter characterized in detail by Mr. Curtis. The specimen from which the alove short description is taken forms part of Mr. Darwin's collection, and was found at Cape Negro. 'The legs are very rough, being thickly covered with tubercles, and they are shorter than in most of the species of Nyctelia. The whole upper surface of the elytra is covered with rugæe, and these are very strongly marked, and though very irregular, they have a general longitudinal direction on the depressed space on the middle of the elytra. This sutural depression, which is about two lines in width, is bounded on each side by a broad and slightly elevated ridge; between this ridge and the outer margin the ruga have a tendency to form oblique lines. A few fine punctures are observable on the fore-part of the thorax, and on the sides are two grooves placed closely together, and parallel 
with and near the lateral margin; the narrow ridge between the two grooves, as well as the marginal ridge, is crenulated.

Nyctelia PUNCTicollis. Nyct. ovata, atra, nitida; thorace distinctè et crebrè punctato; elytris tuberculis minutis, et ad latera rugis transversis irregularitèr impressis, his non forte distinctis.

Long. corp. $9 \frac{3}{4}$ lin. ; lat. 6 lin.

Hab. Bahia Blanca.

This species is rather smaller than the $N$. lavis, and has the thorax and elytra less convex. The head is rather thickly and coarsely punctured, excepting on the vertex. The thorax is thickly and coarsely punctured, and the punctures are for the most part confluent; a distinctly impressed line runs parallel with and close to the margins; the lateral margins are obscurely crenulated. The elytra are of a broad ovate form, and the apical produced portion is convex and rounded at the apex. The lateral keel of the elytra is distinctly crenulated, and transverse shallow furrows run inwards from this margin, leaving interspaces rather broader than the furrows, which, for the most part, are about a line, or rather less, in length. On the interspaces between the furrows, and the whole upper surface of the elytra, are very minute scattered tubercles; these are very indistinct towards the suture, near which are one or two very faint striæ. The labrum is coarsely punctured, and the underside of the head is also punctured. The under surface of the prothorax is covered with small tubercles, from each of which springs a hair; between the legs, the under side of the prothorax and mesothorax is coarsely punctured. The first, second and third of the abdominal segments are covered with distinct longitudinal rugæ, and the apical segments are punctured beneath.

Several specimens of this species were collected at Bahia Blanca by Mr. Darwin, who says they are 'tolerably abundant on sandhillocks.' A Nyctelia in Mr. Darwin's collection, from Rio Negro, resembles the present species, excepting that it has pitchy red legs and antennæ.

Nyctelia subsulcata. Nyct, ovata, atra; thorace transverso distinctè punctato; elytris rugis tuberculisque minutissimis; sulcis transversis aliquanto irregularibus ad latera insculptis.

Long. thoracis elytrorumque, $9 \frac{1}{3}$ lin. ; lat. $5 \frac{2}{3}$ lin.

Hab. Mendoza.

This species is very closely allied to the $N$. puncticollis, and it is with considerable hesitation that I venture to describe it as distinct, more especially as Mr. Darwin's collection contains but one specimen, and that has lost its head and legs; this specimen, however, differs considerably in form from any of the numerous examples of $N$. puncticollis which I have before me. The thorax is narrower and less thickly punctured; the elytra are more elongated, and the lateral transverse grooves are more distinct and regular.

The thorax is transverse, and the length is equal to rather more than half the width; the middle and hinder parts are very nearly equal in width, and the anterior portion is contracted; the surface is 
distinctly punctured, and there are two irregular foveæ on each side of the middle, rather nearer to the mesial line than the outer margin. The elytra are one-fourth longer than broad; the apical portion is moderately produced and somewhat pointed: the whole upper surface of the elytra is covered with very minute rugæ, and there are moreover some minute tubercles; on the outer half of each elytron is a series of transverse furrows, with convex interspaces equal in width to the furrows.

Nyctelia Saundersit. Nyct. atra, oblongo-ovata, nitida; thorace punctato ; elytris sulcis transversis paulo irregularibus a margine laterali usque ad medium ductis.

Long. corp. $7 \frac{\mathrm{I}}{2}$ lin. ; lat. 4 lin.

Hab. Bahia Blanca.

Head distinctly punctured in front. Thorax rather coarsely punctured, excepting on the disc, which is almost impunctate; emarginated in front, the emarginated portion in the form of a segment of a circle; the lateral margin slightly rounded. The hinder part of the thorax and the middle are equal in width; the fore-part is slightly contracted. The elytra are ovate, and but little convex; they are depressed at the suture, most distinctly so near the scutellum. The lateral keel is very prominent, and extending from this keel to the middle of the elytron are distinct transverse furrows, the interspaces of which are convex, and about equal in width to the grooves. The apical portion of the elytra is moderately produced. The three basal segments of the abdomen, as well as the metasternum, are covered with slightly irregular longitudinal rugæ: the terminal segment is punctured. The prosternum and mesosternum are coarsely punctured, and the punctures are confluent.

This is a small species compared with $N$. lavis (being about the size of $N$.nodosa); its form is more elongated and much less convex. The lateral margins of the thorax form an even curve from the front to the back.

The specimens from which the above description is drawn up were found by Mr. Darwin in the month of September, on the sandy plains of Bahia Blanca.

Nyctelia rugosa. Nyct. nigra, opaca, ovata; thorace distinctè punctato; elytris valdè rugosis, sulcis duobus, suturam prope, longitudinalibus et interruptis, impressis.

Long. corp. $7 \frac{3}{4}$; lat. $4 \frac{2}{3}$.

$H a b$. San Blas (near Rio Negro) and Bahia Blanca.

This, which is a small species compared with $N$. lavis, approaches that species in general form, but the thorax and elytra are less convex. The head is coarsely punctured in front. The thorax is coarsely punctured, and the punctures are numerous, excepting on the disc: a groove runs parallel with and close to the margins, but at the posterior margin it is interrupted in the middle. The elytra are convex, and of a short ovate form, and the apical portion is but little produced; their width is about one-fifth less than the length: the whole upper surface is covered with coarse and very irregular rugæ. 
Four somewhat interrupted and irregular strixe run parallel with and near the suture, and there are two abbreviated oblique stria near the scutellum. Besides the ordinary ruga of the elytra, there are more marked rugx, which, though very irregular, huve a tendency to a transverse disposition, and these cover the outer half of each elytron. The prothorax is punctured beneath and rugose between the legs, as well as the mesosternum and metasternum. The three basal segments of the abdomen are covered with fine but distinct rugæ, and though these rugæ, for the most part, have a longitudinal direction, they are much more irregular than in most species of the genus. The two terminal segments are punctured, but in the penultimate segment the punctures are very few in number, and confined to the sides. The spines at the apex of the anterior tibix are more slender and proportionately longer than in $N$. lavis.

Besides the two specimens, one from Bahia Blanca and the other rather further south (San Blas), Mr. Darwin's collection contains a specimen from Tierra del Fuego which is smaller (length 62 lin., width $3 \frac{3}{4}$ lines) and proportionately narrower; but these differences are combined with a greater length of tarsus, and are precisely such differences as exist between the sexes of other species; in fact, it is no doubt the male of the insect from which the above description is taken.

Nyctelia Westwoodir. Nyct. brevitèr ovata, nitida, atra; capite subpunctato; thorace transverso, posticè paulo latiore quam antic̀े, levitèr convexo, levi, margine laterali imperspicuè crenulato; elytris ovatis, profundè striatis, interstitiis convexis, striis utrinque ad suturam duabus longitudinalibus, striis reliquis obliquis.

Long. corp. $7 \frac{1}{2}$ lin. ; lat. $4 \frac{3}{4}$ lin.

Hab. Port Desire.

Head with a few punctures in front. Thorax convex, about twice as broad as long, with the middle and hinder parts about equal in width, and the fore-part contracted; the anterior part emarginated, the emarginated portion in the form of a segment of a circle; the hinder margin but slightly waved; a distinct groove runs close to the anterior and lateral margins, which latter are crenulated. Elytra short and rounded; the length and width equal, if the produced apical portion be omitted in the measurement; the apex is moderately produced : the whole surface of the elytra is covered with deep striæ, leaving convex interspaces which are scarcely broader than the grooves; on each side of, and parallel with the suture, are two of these strix; the remaining grooves are oblique, and for the most part converge towards the apical portion of the elytra: on the sides of the elytra, and more especially towards the apex, the grooves have a tendency to a transverse disposition. The mentum is very coarsely punctured, and there are some distinct punctures on the sides of the head beneath. The prothorax presents a few large scattered punctures beneath, some short irregular (but for the most part transverse) rugæ at the lateral margin, and some longitudinal rugæ near the base of the legs; between the legs the prosternum has some confluent 
punctures; the mesosternum and metasternum have irregular rugx, and the three first abdominal segments have minute longitudinal furrows; the penultimate segment is smooth, and the apical one is finely punctured, but the punctures are by no means numerous. The legs and antennæ are rather shorter than usual in the genus.

Nyctelia Stephensiz. Nyct. atra, nitida, lavis; thorace subquadrato; elytris rotundato-ovatis, convexis, carind laterali prominenti et crenulatâ; elytrorum apicibus productis latis et subcomplanatis.

Long. corp. 7 lin.; lat. $4 \frac{1}{3}$ lin.

Hab. St. Cruz.

Head with scattered punctures in front. Thorax transverse, the width being rather less than double the length; the upper surface is but little convex; the anterior and posterior margins are nearly straight, but the anterior angles are produced and the posterior angles are slightly produced. The width of the fore and hind parts of the thorax is nearly equal, it being but slightly narrower in front, and the sides deviate but little from a straight line; a faint dorsal channel is observable, and a groove runs parallel with and close to the lateral and anterior margins. With the assistance of a strong lens, minute punctures may be observed scattered over the upper surface of the thorax, and some minute tubercles on the under. The elytra are convex, and of a short rounded form, the width and length being very nearly equal, if we do not include the produced apical portion, which is more dilated than in most of the genus, and is nearly flat. A groove runs close to and parallel with the lateral keel, both above and below, and this keel is distinctly crenulated. The upper surface of the elytra presents numerous indistinct and very shallow fovex. The abdominal segments are almost smooth. The legs are proportionately rather longer than in $N$. lavis.

Mr. Darwin found this species at St. Cruz in the month of April.

Nyctelia Newpontir. Nyct. elongato-ovata, nigra, nitida; capite transversè impresso; thorace lato plus quàm longo, lateribus rotundatis; anticè et posticè latitudine compari; supernè minimè convexo, impunctato, ad latera rugis parvulis obliquis ; elytris ovatis, lavibus, plagd suturali valdè impressis, marginibus lateralibus crenulatis.

Hab. Patagonia.

Long. corp. 10 lin.; lat. 6 lin.

This species is rather smaller than $N$. lavis, and differs moreover in being of a more elongated form, and most especially in the form of the thorax, which is narrower and nearly equal in width, in front and behind: the apical portion of the elytra is much less produced, and the produced portion is broader. The head is sparingly punctured at the sides, and has a curved impression, the chord of which is rather in front of the insertion of the antennæ. The thorax nearly one-third broader than long (taking the length from the anterior and posterior angles); it is broadest in the middle, and a trifle nar- 
rower in front than behind; the lateral margins form an even curve; the anterior part is emarginated, the emarginated portion being in the form of a segment of a circle, and a little less than a semicircle: the anterior angles acute, and the posterior angles form very nearly right angles : the hinder margin of the thorax is nearly straight, but the line descends slightly towards the angles. The surface of the thorax is very little convex, and almost impunctate, there being but a few scattered very minute punctures; on the sides, running inwards and upwards, are a series of minute grooves, like scratches, and on the hinder margin a faint trace of very short longitudinal grooves is visible. The elytra are ovate, convex, smooth, and glossy; the region of the suture is broadly and rather deeply depressed; the lateral keel is prominent and distinctly crenulated, and joining this keel are a series of shortish transverse furrows. The under surface of the body and thoracic segments is remarkable for the almost total want of sculpturing, if we except some longitudinal furrows on the under side of the prothorax at the sides.

The exact habitat of the specimen from which the above description is taken is not known, but in Mr. Darwin's collection is a specimen which I am inclined to regard as specifically identical, and which is from St. Julian. It has the elytra proportionately rather broader and the thorax narrower, and the short longitudinal furrows on the hinder margin of the thorax are distinct; the sutural portion of the elytra is less depressed.

Nxctelia GueqINIr. Nyct. atra, nitida, ovata; capite transversim impresso; thorace subquadrato in medio pauld dilatato, anticè emarginato, posticè ferè recto; ad margincm lateralem sulcis minutis valde obliquis insculpto; elytris ovatis, convexis, ad apicem paulo productis, ad latera rugis transversis in seriebus tribus dispositis.

Long. corp. $9 \frac{\mathrm{I}}{2}$ lin.; lat. $5 \frac{3}{4}$ lin.

$H a b$. St. Cruz.

Rather smaller than $N$. leivis. Head with small punctures very thinly scattered over the upper surface, and with a transverse impression rather in front of the line of the eyes. Thorax subquadrate, the breadth not quite equal to twice the length; the emarginated portion in front in the form of a segment of a circle; the hinder margin nearly straight; the posterior angles scarcely produced, and forming nearly right angles; the anterior angles acute. The thorax is contracted in front, broadest in the middle, and the lateral margin from the middle to the posterior angles forms nearly a straight line : on the hinder part of the upper surface are some extremely minute punctures, and at the sides are some small oblique grooves. The elytra are ovate and moderately convex, and the apical portion is but little produced; the region of the suture is very slightly indented: the sides of the elytra are covered with transverse grooves having narrow convex interspaces; these grooves extend inwards to about the middle of each elytron, and are arranged in three series, being divided by two longitudinal lines; the innermost 
series is indistinct : the lateral keel is distinctly crenulated. The mentum is distinctly punctured; the prosternum, as well as the other thoracic segments, and the abdominal segments, have the usual sculpturing, but it is less strong than usual.

It is with some hesitation that I name this insect, since it approaches very near to the $N$. Newportii; it differs, however, in having the thorax smaller and proportionately narrower, the elytra less convex, and furnished at the sides with three rows of transverse impressions instead of one; the region of the suture is less depressed.

Nyctelia sulcicollis. Nyct. ovata, atra; thorace transverso, ad latera rotundato, anticè angustiore, sulcis minutis longitudinalitèr impresso ; elytris crebrè punctatis (punctis confluentibus), tuberculisque minutis instructis: capite, thorace elytrorumque lateribus pilis vestitis, pedibusque etiam pilis instructis.

Long. corp. $8 \frac{\mathrm{I}}{4}$ lin. ; lat. $5 \frac{\mathrm{I}}{2}$ lin.

Hab. St. Cruz.

Much smaller than N. levis, and of a shorter and more rounded form. The upper surface of the head is very thickly punctured throughout, and the punctures run into each other so as to form irregular ruge. The thorax is twice as broad as long, and has a deep and almost semicircular emargination in front; the anterior angles are acute, and the posterior angles are obtuse, and not produced as in many species of the genus, the hinder margin of the thorax presenting a nearly straight, or but very slightly waved line: the broadest part of the thorax is near the posterior angles, the narrowest part is in front, and the lateral margins are rounded in such a manner that the thorax might almost be described as semicircular, and having the fore-part emarginated. The whole upper surface of the thorax is covered with small but distinct grooves, leaving convex ridges between them about equal in width to the grooves; these furrows are longitudinal in their direction, or very nearly so, excepting in the fore-part, where they diverge from the mesial line and run up to the anterior margin, and at the sides of the thorax, where the grooves are irregular, but have a tendency to a transverse disposition. The under side of the thorax presents similar longitudinal grooves, excepting in the middle, where it is rugosely punctured; scattered hairs cover this under surface of the thorax; and towards the lateral margin the hairs, which are moderately long, are much more numerous and form a projecting fringe, which is visible when the insect is viewed from above. The elytra are of a short ovate form, about one-fourth broader than the thorax, and scarcely one- fifth longer than broad; the apical portion is but little produced: the upper surface is convex, and is thickly covered with small confluent punctures, amongst which minute tubercles are scattered; towards the lateral keel, which is very little prominent, the tubercles are distinct. The sculpturing of the portion of the elytra beneath the keel resembles that above it, but here the tubercles give origin to small hairs ${ }^{*}$. The meso- and metasternum present irregular rugæ.

- Probably similar hairs originally sprang from the tubercles on the upper surface, but have been worn off. 
On the first and basal half of the second abdominal segments are distinct longitudinal ruga, and a slight trace of similar rugæ is observed at the base of the third segment; on other parts of these segments are some minute scattered punctures. The terminal segment is rather thickly though finely punctured. The legs are clothed with longish ash-coloured hairs.

Nyctelia nodosa, Latr. Zophosis nodosa, Germar?

Five specimens of this species are contained in the collection of Mr. Darwin, and these are from three different localities; viz. Maldonado (La Plata), Bahia Blanca, and Mendoza.

Nrctelia angustata. Nyct. atru, elongata, nitida; capite distinctè punctato et tranverstm impresso ; antennis piceis; thorace subquadrato, lateribus ferè rectis, anticè emarginato, suprà punctis minutissimis; elytris subelongatis, et cum thorace quoad latitudinem ferè cocequalibus, costis aliquantò irregularibus subelevatis interstitiis rugulosis, ad latera plicis transversalibus.

Long. corp. $7 \frac{1}{4}$ lin.; lat. $3 \frac{2}{3}$ lin.

Hab. Patagonia?

The specimen from which the above characters are taken is a male, and by accident its label, containing the kabitat, is lost; it is most probably from Patagonia. In general appearance the $N$. angustata greatly resembles the $N$. nodosa, but it differs in being of a narrower form, and in having the terminal joints (the fifth to the tenth inclusive) broader; the anterior tibiæ are also broader and rather shorter, and the thorax is longer in proportion to the width.

The head is distinctly and very thickly punctured in front. The thorax approaches to a quadrate form, but is slightly narrower in front than behind; the lateral margins form a very slight curve, and in fact are nearly straight ; in front it is emarginated, and the emarginated portion is in the form of a segment of a circle; the hinder margin is but little waved; the anterior angles are acute, and the posterior angles are slightly produced and rounded at the point; a faint impressed line borders the anterior and lateral margins : the upper surface is but little convex and finely punctured, but on the disc the punctures are scarcely traceable : the length of the thorax is about equal to three-fifths of the width, whereas in $N$. nodosa the length is about equal to half the width. The elytra are very little broader than the thorax, being scarcely dilated in the middle, and are about one-third longer than broad; they have interrupted and somewhat irregular longitudinal grooves or strix, and the interspaces are convex; the third and fifth most distinctly so : the strix and interspaces on the lateral half of each elytron have distinct irregular rugæ, the largest of which are for the most part transverse in direction: the legs are long; the claws are of a pitchy colour. The fifth, sixth, seventh and eighth joints of the antennæ are somewhat compressed, broader than long, and produced in front so as to present nearly a triangular form; the ninth and tenth are still broad, but of a somewhat rounded form. 


\section{Genus Epipedonota.}

Epipedonota rugosa. Epip. atra, opaca: capite rugoso; thorace lato plusquàm longo, posticè angustiore, depresso supernè rugis valdè irregularibus, illis apud marginem exteriorem plerùmque longitudinalibus, illis apud discum ferè transversis, et utrinque costa majore sublongitudinali definitis; elytris subovatis undattm rugis plerùmque transversis, et utrinque costâ apud discum valdè elevatâ, deindè altera minus elevatd inter illam et carinam lateralem.

Long. corp. $8 \frac{1}{2}$ lin.; lat. $3 \frac{3}{4}$ lin. ; vel, long. $11 \frac{1}{3}$; lat. $5 \frac{3}{4}$.

Hab. Petorca?

The whole upper surface of this insect is covered with well-marked irregular rugæ; these are for the most part longitudinal in their direction on the clypeus, and there is a transverse indentation marking the posterior boundary of this part: a little behind the line of the eyes is a somewhat irregular transverse ridge, and in the middle, between this ridge and the transverse groove just mentioned, is a short longitudinal ridge. The labrum is rugosely punctured. The thorax is very nearly twice as broad as long; its anterior and posterior margins are nearly straight, excepting near the lateral angles, which are produced. Besides the ordinary rugæ on the thorax, there are two large longitudinal and slightly curved ridges, situated one on each side, nearly midway between the mesial line and the outer margin; and on each elytron is a strongly elevated costa or ridge, extending from the base very nearly to the apex, and running nearly parallel with the lateral keel of the elytron, on the mesial line of which they are placed. The spaces between these costæ is somewhat concave, and so is the interstice of the costa and the lateral keel of the elytron, which is crenulated or irregularly indented. The mentum is very coarsely punctured, and the punctures are confluent. 'The under side of the head is punctured, and there are numerous coarse punctures on the prosternum between the legs. The basal segments of the abdomen have small longitudinal sulci beneath.

Besides the great difference in size and form indicated by the dimensions, there occurs sometimes a difference in the sculpturing of the thorax and elytra, which I could scarcely have believed to exist in the same species had I not had an opportunity of examining many specimens. In a specimen before me, the ruga on the head, thorax and elytra are much less distinct than in the individuals from which the above description is taken; and this is combined with a convexity of the elytra (which are almost always concave between the two dorsal costæ and also between these costæ and the lateral keel), giving a very different aspect to the specimen under consideration.

In having the thorax distinctly contracted behind, and in the more truly moniliform structure of the antennæ, the present insect approaches more nearly to Callyntra than to Epipedonota, but the terminal joint of the antennæ is decidedly smaller than the rest. I have before me specimens of the Callyntra multicostata and Call. vicina (which I scarcely think a distinct species), and do not find so marked 
a difference in the size of the.terminal joint of the antenna as compared with the penultimate joint, as that represented by M. Solier's figure-indeed the penultimate joint and terminal appear to me to be equal in size, or most nearly so.

EpIPedonoti arfinis. Epip. atra, nitida : capite anticè punctis sparsis, et posticè rugis transversis undulatis, notato; thorace latiore quàm longo, ad medium depresso, rugis vel plicis ferè longitudinalibus, ad latera transversis notato ; elytris thorace latioribus, propè suturam ferè lavibus, singulorum dimidio externo sulcis transversis, his costa longitudinali, in duas series divisis; prosterno sulcis distinctis longitudinalibus; segmentis abdominalibus levitèr longitudinali-sulcatis.

Long. corp. $9 \frac{1}{2}$ lin. ; lat. $5 \frac{1}{3}$ lin.

Hab. Petorca?

This species is of a shorter and broader form than Epip. ebenina, the furrows on the thorax are smaller and more numerous, and the elytra present but one distinct costa besides the lateral keel, the ridge corresponding to that nearest the suture in E. ebenina, being here obliterated, or very nearly so.

The head presents some scattered punctures in front, and, generally, there are some waved transverse impressions towards the hinder part, leaving narrow ridges between them. The thorax is twice as broad as long, has the sides distinctly rounded, the fore-part emarginated in the form of a segment of a circle; the anterior angles are acute, and there is a small indentation in the outer margin close to the angle; the posterior margin is nearly straight in the middle, but the angles are produced: the upper part of the thorax presents a slightly concave surface, and is covered with small sulci; those in the middle are oblique, converging to or towards the hinder part of the mesial line; about midway between this line and the outer margin they become longitudinal in their direction, and a space bordering the lateral margin is covered with oblique but nearly transverse narrow grooves and ridges. The width of the elytra, compared with that of the thorax, is nearly as seven to five, and the elytra are about one-fourth longer than broad, or rather less; the dorsal surface is plane and almost destitute of sculpturing; on the sides are two series of transverse furrows, which are separated by a strong costal ridge; the innermost of these two series of transverse grooves is obliterated towards the base and apex of the elytron, but in the middle they are strongly marked, as are also the transverse grooves between the costal ridge and the lateral keel : on the apical half of each elytron a faint trace of the costa, corresponding to the innermost one in $E$. ebenina, is observable.

Numerous specimens of this new species were contained in $\mathrm{Mr}$. Bridges's collection.

Epipedonota ebenina, Solier. Nyctelia ebenina, Auct.

Four specimens of this species were brought by Mr. Darwin from Mendoza; two of these are females, and present a character $I$ have not before observed in the species, viz. some zigzag white lines at 
the apex of the elytra; these lines are observable in the grooves between the costæ : in one specimen there are three of the white lines on each elytron, corresponding with the number of interspaces of the costæ; they are interrupted, and form dots as they recede from the apex of the elytron. In the other specimen there are but two of these lines visible.

Epipedonota erythropus, Solier. Nyctelia erythropus, Auct.

Mr. Darwin also found this species (if it be really distinct from ebenina) at Mendoza.

Epipedonota Bonariensis. Epip, atra, nitida; thorace suprà irregulariter et longitudinaliter multiplicato, ad latera crenato ; elytris utrinque costis duabus elevatis, et sulcis transversalibus ordine triplici.

Long. corp. $11 \frac{1}{2}$ lin.; lat. $5 \frac{3}{4}$ lin. ; vel, long. $9 \frac{2}{3}$ lin. ; lat. 5 lin. $H a b$. Monte Video and Bahia Blanca.

The species nearly resembles the $E$. ebenina, but differs in bein $\delta$ larger and proportionately broader; as in $E$. ebenina, each elytron has two longitudinal elevated costæ besides the lateral keel; but the interspaces of all the costæ are indented with transverse furrows, whereas in $\boldsymbol{E}$. ebenina only the two outermost interspaces have these furrows, and here they are much less strongly marked. The lateral keel in $\boldsymbol{E}$. ebenina presents a nearly even line, but in $\boldsymbol{E}$. Bonariensis the keel is distinctly indented; the sulci on the thorax are less strongly marked and more numerous. tion.

Seven specimens of this species occur in Mr. Darwin's collec-

Eripedonota lata. Epip. atra, nitida, lata; capite punctis dispersis anticè, apuḋ medium sulco transverso, et posticè sulcis paucis obliquis; thorace sulcis, his obliquis, illis apud medium longitudinalibus, illis margini proximis transversis, insculpto; elytris convexis costis latis paul〉 elevatis posticè subobliteratis, spatio inter costam secundam et carinam externam, sulcis profundis transversis notato.

Long. corp. $9 \frac{3}{4}$ lin. ; lat. 6 lin.; vel, long. $8 \frac{2}{3}$ lin. ; lat. 5 lin.

Hab. Port Desire.

This species is larger and proportionally much broader than $\boldsymbol{E}$. ebenina. The thorax, in proportion to the size of the insect, is much broader than in any other species of Epipedonota here described, the width being nearly equal to two-thirds of the length of the elytra; whereas in $E$. affinis, which I have described as a shorter and broader species than $E$. ebenina, the width of the thorax is scarcely more than equal to half the length of the elytra.

The head is punctured in front and has some waved transverse grooves and ridges between the eyes. The thorax is about twice as broad as long, emarginated in front nearly in the form of a segment of a circle; the lateral margins are rounded; it is widest a little behind the middle and narrowest in front; the anterior and posterior angles are acute; the upper surface is nearly flat, but the lateral margins are slightly reflected; the anterior mesial portion is a little convex, and 
the posterior mesial portion is sometimes slightly concave; the whole surface is covered with narrow grooves and ridges; those on the dorsal part of the thorax are longitudinal but slightly irregular, towards the sides they are oblique, diverging slightly behind, and a broadish space at the sides is covered with sub-transverse grooves, these being directed inwards and slightly upwards from the lateral margin. The width of the elytra, as compared with the length, is as 4 to 5 ; their upper surface is convex, excepting at the base, where they are somewhat depressed : on each elytron are three longitudinal narrow grooves, these are distinct and wavy at the base of the elytra; the first groove, or that nearest the suture, is obliterated on the hinder half of the elytron; the second is continued nearly to the apex, but from the base it becomes gradually less distinct; the third extends to the apex, and forms as it were the outer boundary to the convex portion of the elytra for the space between the last-mentioned line and the lateral keel, which is nearly equal in width to one-third of that of the elytron, is nearly flat, or even slightly concave in the males; on this space is a series of deep transverse indentations, leaving convex interstices of a width corresponding to that of the grooves. The two interspaces between the first, second and third striæ of each elytron are very broad and slightly convex; and on the second or outermost of these interspaces are a few oblique furrows, which are not very distinct, and for the most part rather widely separated. Besides the longitudinal striæ mentioned, there are some others, but these are short and confined to the base of the elytra; in the males about five or six longitudinal grooves may be seen at the base of each elytron, and all of these grooves are more or less wavy. The sides of the prosternum present distinct longitudinal sulci, and narrow longitudinal sulci are observable on the abdominal segments.

Three specimens of this new species were brought from Port Desire by Mr. Darwin.

Genus Callyntra, Solier.

Callyntra vicina, Solier. One specimen of this species was braught from Valparaiso by Mr. Darwin.

Genus Cerostena; Solier.

Cerostena punctulata. Cer. atra, elongato-ovata; capite crebrè punctato et transversim impresso; thorace transverso, anticè profundè emarginato, suprà ferè plano, punctato ; marginibus lateralibus reflexis, disco foveis duabus impresso; elytris oblongo-ovatis, pauld convexis, suprà punctulatis, singulis costis duabus dorsali: bus subobliteratis; carina laterali pauld prominente.

Long. corp. $8 \frac{3}{4}$ lin. ; lat. $4 \frac{3}{4}$ lin.

$H a b$. St. Cruz.

In general appearance the present species resembles the Blaps obtusa, but the thorax is much shorter and the body more depressed. On the hinder part and sides of the elytra is an ashy pubescence, and I think it probable that small hairs have originally been scattered over the whole upper part of the elytra and have been rubbed off the most exposed parts. On the under side of the head and body 
small hairs are also perceptible in the less exposed parts. The prosternum is very rugose beneath on the fore-part, and has distinct longitudinal furrows at the sides, as has also the mesothorax; the abdominal segments are thickly punctured, and there are longitudinal rugæ on the basal segments. The legs and tarsi are moderately well clothed with small yellowish hairs.

Unfortunately the antennæ are not perfect in the only specimen which Mr. Darwin brought home of this species; in the characters afforded by other parts, however, it agrees with M. Soliet's genus Cerostena: the absence of sulci on the upper surface of the thorax would serve to distinguish it from the species of that genus bitherto described.

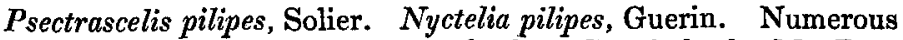
specimens of this species were brought from Coquimbo by Mr. Darwin.

Entomoderes Erebi, Solier. Mr. Darwin's collection contains one specimen of this curious insect, and this was found at Mendoza.

Mr. Waterhouse next proceeded to characterize the following new species of Curculionide from the collections of Mr. Darwin and Mr. Bridges.

\section{Divisio CLEONIDES, Schoenherr.}

\section{Genus Listroderes, Scho.}

LISTRODERES sUBCostatus. Listr. niger, opacus, fusco-squamosus; antennis piceis ; rostro brevi, carinato; thorace punctatissimo, subquadrato, posticè angustiore, setis fuscescentibus instructo; elytris punctato-striatis, fusco-setosis, interstitiis alternatis subelevatis.

Long. corp. et rostri, 6 lin.; lat. $2 \frac{1}{4}$ lin.; long. $4 \frac{3}{4}$, lat. 2 lin.

$\mathrm{Hab}$. Valleys of Petorca.

Rostrum about half as long again as the head, with three costr above, the central one but little developed, and the lateral costæ in, distinct; the space between the costæ finely rugose; the whole surface of the rostrum covered with distinct yellowish hairs. Head thickly punctured, the punctures confluent, and with an impressed point between the eyes. Thorax about one-third broader than long, emarginated in front, nearly straight behind, but slightly indented in the middle; the broadest part of the thorax is about the anterior third; from this point it is contracted in width, both before and behind, in nearly equal proportions; the upper surface is nearly flat, and very thickly and distinctly punctured; the punctures more or less confluent; a faint dorsal ridge is sometimes perceptible; small spiny semierect hairs cover the thorax; elytra moderately long, with the humeral angles forming right angles; the apex rounded, the width about one-fourth greater than that of the thorax; the upper surface moderately convex, covered with brown scales, and having interspersed erect spiny hairs; punctate-strinted, the interstices very finely shagreened; the third, fifth, and the seventh from the suture, raised; a few black spots are irregularly scattered over the elytra, 
and in some specimens are some whitish spots arranged in lines on the apical portion of the elytra.

From the collection of Mr. Bridges.

Listroderes pilosus. Listr. niger, opacus, setosus, fusco-squamosus ; antennis tarsisque fuscescentibus; rostro indistinctissimè carinato; thorace crebrè punctato, subquadrato, lateribus subrotundatis; elytris punctato-striatis. Capite, thorace, elytrisque squamis fuscis atque nigrescentibus densè tectis.

Long. corp. et rostri, $3 \frac{1}{3}$ lin. ; lat. $1 \frac{1}{4}$ lin.

$H a b$. Valleys of Petorca.

About equal in size to Sitona fusca. Rostrum a trifle longer than the head, slightly rugose, and with a very indistinct longitudinal carina. Head thickly punctured, the punctures confluent, and an impressed line between the eyes. Thorax subquadrate, and somewhat depressed ; very thickly, but not coarsely punctured, the punctures confluent; the width greater than the length; the sides nearly straight and parallel, excepting near the base and apex of the thorax, where the width is gradually contracted. Elytra but little wider than the thorax, somewhat convex and elongated; the humeral angles rounded, and the apical portion rather attenuated, but with the tip rounded; the sides subparallel; punctate-striated; the punctures, of moderate size, are rather close together; the interstices of the striæ nearly flat, and apparently slightly rugose.

The sculpturing of the rostrum, head, thorax and elytra is with difficulty examined, all these parts being densely clothed with scales; these are chiefly of a brown colour, but in parts they are of a blackish hue. On the thorax is an indistinct dusky line in the middle, and one or two dusky patches at the sides; the elytra are variegated with deep and pale brown.

From the collection of $\mathrm{Mr}$. Bridges.

Listroderes costirostris, Scho. Several specimens of this species are contained in Mr. Darwin's collection, having been collected at Maldonado; and there are, moreover, specimens collected at Coquimbo which present no distinguishing character, excepting in being of a larger size, viz. total length $5 \frac{1}{2}$ lines, width $2 \frac{1}{4}$ lin.; those from Maldonado being $4 \frac{1}{2}$ lines in length and $1 \frac{3}{4}$ in width.

Listroderes noBUstus. Listr. breviter ovatus, niger, opacus, fusco-squamosus, setosus; antennis fuscescentibus ; rostro longiusculo, carinato, pilis minutis decumbentibus tecto; thorace crebrè punctulato, brevi, vittâ alba ornato, lateribus subrotundatis ; elytris breviter ovatis, punctato-striatis, fascid albescente, ad latera interrupta, ornatis, singulatim tuberculo subapicali instructis.

Long. corp. et rostri, $4 \frac{1}{3}$ lin. ; lat. $2 \frac{1}{5}$ lin.

Hab. Coquimbo.

In size and form this species may be compared to the Phytonomus punctatus. Rostrum about twice as long as the head, covered with minute decumbent brownish hairs, and with a Jongitudinal carina. Thorax rather broader than long, very suddenly contracted in front, and broadest near the fore-part; the sides slightly rounded, or nearly 
straight; the posterior angles rounded, and the posterior margin indistinctly produced in the middle; the surface very thickly punctured and covered with pale brownish scales, and having interspersed minute hairs ; in parts the scales assume a deeper hue, and in the middle is a whitish line. Elytra about one-third broader than the thorax, convex, and of a short ovate form ; punctate-striated; the interstices obscurely punctured, and slightly convex; they are covered with brownish scales, and have interspersed minute pale hairs; rather behind the middle is a broadish curved mark, which is obliterated on the sides of the elytra; and towards the apex is a small angular tubercle.

From the collection of Mr. Darwin.

Listroderes apICALIS. Listr. squamosus, fusco-albescens; antennis piceis; rostro cariná longitudinali fuscâ; capite notis duabus fuscis anticè convergentibus; thorace anticè quam posticè latiore, ad latera ferè recto, anticè foved incurvata, lined alba longitudinali; elytris thorace duplo latioribus, punctato-striatis ; singulis nota nigrescente obliqua, ad apicem albescente, tuberculo distincto subapicali.

Long. corp. et rostri, $3 \frac{1}{4}$; lat. $1 \frac{1}{3}$ lin.

$H a b$. Monte Video.

This species is considerably less than the $L$. castirostris, being about equal in size to the Phytonomus rumicis. The rostrum is rather slender, nearly twice as long as the head, covered with minute decumbent hairs, which are of a whitish brown colour; in the middle is a longitudinal carina. The thorax is broader than long; the broadest part is considerably in front of the middle; in front it becomes somewhat suddenly contracted; the sides of the thorax converge from near the anterior part towards the base, and are nearly parallel; the posterior margin is slightly rounded, being produced in the middle; the hinder angles are obtuse; the upper surface of the thorax is nearly plane, presenting scarcely any convexity, and in the fore-part is a curved impression, the extremities of which lead up to the anterior angles; it is densely clothed with scales, and these are of a very pale brownish colour; in parts the scales are of a deep brown colour, and in the middle is a longitudinal line, formed of whitish scales; besides the scales are some very minute, semierect, scattered dusky hairs ; the sculpturing cannot well be seen, owing to the cover ing of scales, but the thorax appears to be very thickly though not coarsely punctured. The elytra are oblong, about one-third broader than the thorax; the humeral angles are prominent and rounded; the sides nearly straight, and the apex rounded; the surface is convex, but somewhat depressed at the basal portion of the elytra; punctate-striated; covered with pale brownish scales, having moreover some very minute scattered spines; the third and fifth interstices of the strix on each elytron are slightly raised; rather behind the middle is an oblique deep brown patch, behind which the scales are white, or nearly so ; a distinct angular tubercle is observable on each elytron, at a short distance from the apex. 'The legs and antennæ are brown, 
and covered with minute palish hairs; near the apex of each of the femora is a whitish ring.

In the collection of Mr. Bridges are several species of Curculionide. closely allied to Listroderes, but differing in having the antennæ more slender and elongated; the club is very long, distinctly jointed, and very slightly incrassated ; the legs are longer, and the body is covered with minute hairs, or hair-like scales, whilst all the species of Listroderes examined by me have the body distinctly clothed with scales. Moreover, in none of the insects under consideration do I find the tubercles on the apical portion of the elytra, which are so common in the Listroderes. Such differences, though readily seen, it is impossible to express by a generic term. I have determined to designate this new genus by the name

\section{Adroristus*, nov. gen.}

Antennce longæ, tenues; scapus ad apicem subincrassatus; articuli funiculi obconici, $1^{\circ}$ longo ; clava elongata distinctè triarticulata.

Rostrum capite ferè duplo longius, crassiusculum, subarcuatum, versus apicem incrassatum, suprà carinatum : mandibulæ tenues paulo elongatæ.

Oculi subovati, subdepressi.

Thorax transversus, ponè oculos lobatus, suprà subdepressus.

Elytra elongato-ovata, convexa, ad apicem rotundata.

Tarsi elongati, subtenues, subtùs spongiosi.

Adonistus punctulatus. Ad. niger, fusco-pilosus; antennis, tibiis tarsisque piceis ; rostro brevi, crasso, carinato ; thorace punctulato, brevi subquadrato, anticè angustiori, posticè utrinque subemarginato; elytris oblongo-ovatis, convexis, punctato-striatis, interstitiis alternatis maculis parvulis nigris atque albescentibus ornatis.

Long. corp. et rostri, $6 \frac{1}{3}-8 \frac{2}{3}$ lin. ; lat. $2 \frac{1}{2}-3 \frac{1}{3}$ lin.

$H a b$. Valleys of Petorca.

The whole insect is covered with minute decumbent hairs, and these are of an ashy-brown colour. The rostrum is stout, considerably dilated at the apex, and about twice as long as the head; rugose, and has fine longitudinal keels on the upper surface, of which the central one is most strongly developed, and the one next it on each side indistinct. The head is convex above, and thickly punctured. The thorax is about one-third broader than long; the anterior margin is straight, and the lateral margins are very nearly straight; the anterior part is rather narrower than the hinder part; the hinder margin is in the form of a segment of a circle, being produced in the middle, and joins the lateral margin so as to form a somewhat salient but obtuse angle; the upper surface is but very slightly convex, and thickly and distinctly punctured. The elytra are convex, and of an elongate-ovate form, and scarcely one-third broader than the thorax; the upper surface is densely clothed with minute hairs; punctate-striated, the punctures not very large, and distinctly separated; the interstices are plane, or indistinctly convex,

* From diòsógtaros, undefined, \&c. 
and are very finely punctured. On each stria is a series of small black and whitish spots, and these most of them are oblong.

Adronistus angustatus. Ad.niger, fusco-pilosus; antennis, tibiis tarsisque fuscescentibus ; rostro brevi, crasso, carinato; thorace punctulato ad latera et postice subrotundato; elytris thorace paulo latioribus, elongatis, subovatis, punctato-striatis, maculis parvulis nigris ornatis.

Long. corp. et rostri, $5 \frac{\mathrm{I}}{2}$ lin.; lat. 2 lin.

$H a b$. Valleys of Petorca.

This species closely resembles the last in many respects, and especially in its colouring, and in being covered with minute ashy-brown decumbent hairs, but it is of a narrower and more elongated form, and of a much smaller size.

The rostrum is about half as long again as the head, rugose, and has three parallel keels on the upper surface, of which the central one is the most prominent. The head is thickly punctured. The thorax is scarcely one-third broader than long, slightly emarginated in front; the sides are nearly straight and parallel, but near the anterior part they gradually converge, so as slightly to contract the width of the thorax at this part; about the posterior third of the thorax the sides also converge towards the posterior margin, so that the thorax may be described as obliquely truncated on each side behind: the posterior margin is straight; the upper surface is nearly fiat, and thickly and distinctly punctured. The elytra are moderately convex and of an elongated ovate form, and about half as broad again as the thorax; punctate-striated, the punctures of moderate size and distinctly separated, excepting on the hinder part of the elytra; they are densely clothed with decumbent ashy-brown hairs, and on each stria is a series of oblong blackish spots; the interstices are very delicately but thickly punctured.

Adioristus conspersus. Ad. niger, subopacus, fusco-pilosus; antennis tarsisque fuscescentibus; rostro brevi, crasso, carinato; thorace punctatissimo, subquadrato, posticè pauld angustiore, modicè convexo, lateribus subrotundatis; elytris quoad latitudinem thorace ferè corqualibus, lateribus subparallelis, punctato-striatis, interstitiis planis.

Long. corp. et rostri, $5 \frac{1}{2}$ lin. ; lat. $2 \frac{1}{4}$ lin.

Hab. Valleys of Petorca.

Rostrum about half as long again as the head, much dilated at the apex, with three distinct carina, and the two outer carinæ converging slightly towards the base of the rostrum; between the carinæ are minute longitudinal rugæ, but these are hidden by the numerous small brownish hairs which cover this and other parts of the insect. The head is thickly punctured, and there is a minute oblong depression between the eyes. The thorax is subquadrate, about one-fourth broader than long; the anterior margin is straight; the sides are slightly rounded, but nearly straight towards the hinder part of the thorax; the greatest width is at the anterior third; the posterior 
margin is straight, and the posterior angles are very nearly right angles; the upper surface is nearly flat, being but very slightly convex, and thickly but rather finely punctured. The elytra are moderately elongated, but little broader than the thorax, and moderately convex above; the sides are nearly parallel, being very little dilated in the middle; the apical portion is rounded; they are punctate-striated, and the interstices are finely punctured; a series of small blackish spots is observable on each of the stria ; on other parts the very minute hairs which cover the elytra are brownish.

Adrorrstus sryplex. Ad. piceo-niger, pilis fuscescentibus tectus; antennis piceis ; rostro brevi, carinato, ad basin transversim impresso; thorace rugoso-punctato, subcylindraceo, lateribus pauld rotundatis; elytris oblongo-ovatis, punctato-striatis, punctis aliquantò profundis, interstitiis ferè planis et punctulatis.

Long. corp. et rostri, $3 \frac{3}{4}$ lin.; lat. $1 \frac{2}{5}$ lin.

$\boldsymbol{H} a b$. Valleys of Petorca.

A small species, about equal in size to Phyllobius alneti. The rostrum short and stout, being but little longer than the head, is furnished with a central carina and a carina on each side, which is less distinct, and the space between these ridges has longitudinal rugre, which are partially hidden by the scattered hairs which cover this and all other parts of the body. The head is thickly punctured, and the punctures are confluent; a small oblong impression is observable between the eyes, and in front of the eyes is a transverse depression, separating, as it were, the rostrum from the head. The thorax is nearly cylindrical, broader than long, and slightly narrower behind than near the fore-part; the anterior and posterior margins are straight; the upper surface is thickly and rather coarsely punctured, and the punctures are many of them confluent. The elytra are of an elongated ovate form, convex, somewhat attenuated, but rounded at the apex; punctate-striated, the punctures moderately large and rather deep, and nearly joining each other; the interspaces between the striæ are nearly plane, indistinctly punctured in parts and slightly rugose; the minute but somewhat spiny hairs which cover the elytra are not sufficiently abundant to hide the sculpturing, and are semi-erect.

A species of the present genus is contained in Mr. Darwin's col-lection, which differs from either of the above: it is almost destitute of the small hairs which give the brownish colouring to the other species here described.

Adronistus stbdenunatus. Ad. oblongus, niger, pilis minutissimis atque squamulis albescentibus adspersus; antennis tarsisque fuscescentibus ; rostra carinato, punctulato; capite inter oculos transversìm impresso, crebrè punctulato; thorace subcylindraceo in medium pauld dilatato, punctis minutis impresso; elytris oblongoovatis, punctato-striatis, interstitiis pauld convexis, obsoletè punctulatis.

Long. corp. et rostri, $6 \frac{1}{2}$ lin.; lat. $2 \frac{1}{2}$ lin.

Hab. Mendoza. 
This insect is intermediate in size between the $A d$. punctulatus and $A d$. angustatus, and is readily distinguished from either of the species here described by its denuded appearance; the scales and hairs, which are sparingly scattered over the body, only become visible with the assistance of a moderately strong lens.

The rostrum is about twice as long as the head, very thickly though finely punctured, and the punctures are confluent; in the middle is a distinct carina. The head is separated from the rostrum by a transverse and somewhat shallow depression, and in the middle of this depression is a small fovea: the upper surface of the head, as well as the thorax, is very thickly and finely punctured, and the punctures are confluent. The thorax is rather broader than long, subcylindrical, truncated before and behind; the upper surface is slightly convex, and the sides are somewhat rounded, being slightly dilated a little in front of the middle. The elytra are of an elongateoval form, moderately convex, somewhat attenuated at the apex, but with that part rounded; they are distinctly,punctate-striated; the punctures are arranged closely together, and the interstices of the stria are narrow, slightly convex, and very delicately punctured.

Cylydrorhinus angulatus.-Under this name M. Guerin-Meneville describes, in the 'Revue Zoologique' (No. 7, 1841, p. 217), a species of Curculio, from Port Famine, which $I$ am inclined to regard as specifically identical with specimens brought by Mr. Darwin from St. Cruz and St. Julian.

M, Guerin states that the elytra are covered above with large deep punctures arranged in longitudinal striæ, at the base of each of which is a very small tubercle, and which are united together by an indistinct transverse impression.

In the specimens brought by Mr. Darwin, the elytra are deeply punctate-striate at the base, but from the base towards the apex the punctures gradually decrease in size; the minute tubercles are situated on the anterior margin of each puncture, and in addition to the strix of punctures, the elytra are for the most part covered with somewhat irregular transverse rugæ; these are most distinct on the sides of the elytra (or rather what appears to be the side, for the elytra are strongly keeled at some little distance from the lateral margin, so that that part is hidden as we view the insect from above), less distinct on the apical portion, and do not extend to the disc. The apical portion of each elytron is slightly produced, and the elytra appear as it were terminated by a tubercle; near the apex, on each side, is another tubercle. The thorax has a distinct fovea on each side, in the middle and near the lateral margin. The size of the specimens from Port St. Cruz varies from length $9 \frac{1}{2}$ lin., width $4 \frac{1}{3}$ lin., to length $7 \frac{3}{4}$ lin., width $3 \frac{1}{3}$ lin.

A specimen from St. Julian differs in being considerably smaller and more deeply sculptured, and in having a small patch of white scales near the apex of the elytra; the interstice between the fourth and fifth striæ is somewhat raised. Length 7 lines.

In the collection is a specimen, without label, which agrees with this variety, as I presume it is. Length $6 \frac{1}{2}$ lines. 
Two out of three specimens from St. Cruz have pitchy red colour legs ; in the third the legs are black. The specimen from St. Julian has also black legs.

Mr. Darwin found this Curculio "lying dead by thousands on all parts of the plains at St. Julian, both far in the interior and near the coast."

December 28, 1841.

No Meeting took place. 